\title{
Introduction to Part One of the Symposium on The Thought of Work
}

\author{
Victor G. Devinatz
}

Published online: 22 September 2012

(C) Springer Science+Business Media, LLC 2012

In this issue's Perspectives section, I am most pleased to present the first part of the symposium on the recently-published book, The Thought of Work, authored by Dr. John Budd, the Industrial Relations Land Grant Chair in the Department of Work and Organizations at the University of Minnesota. In this landmark volume, Budd examines work from ten perspectives - work as a curse, work as freedom, work as a commodity, work as occupational citizenship, work as disutility, work as personal fulfillment, work as a social relation, work as caring for others, work as identity and work as service. Besides explicating the meaning of work from these various viewpoints, Budd argues that how work is conceptualized is not merely a scholarly exercise for academics but matters deeply in such things as policy development and implementation in the real world.

This symposium consists of three essays written by three outstanding scholars in different disciplines. In the first article entitled, "Work, Free Will and Law", Professor Marion Crain, the Wiley B. Rutledge Professor of Law at the Washington University School of Law, contends that Budd's conceptualization of work is critical to considerations for understanding how law regulates, or should regulate, work in the United States. In the second piece entitled, "Imagining the Thought of Work," Dr. Tim Strangleman, Professor of Sociology at the University of Kent (United Kingdom), argues that Budd's volume helps us to understand the paradox of labor and the workplace through the use of oral history and non-academic writing as revealed by workers themselves. In the third essay entitled, "The Thought of Work: A Review," Dr. Charles Whalen, principal analyst in the Macroeconomic Analysis Division of the Congressional Budget Office, contends that Budd's book indicates the complex and textured nature of work and how the work experience is crucial for analyzing the human experience. While pointing out that Budd does not present an integrative model in his volume, Whalen proposes that The Thought of Work can be integrated with John Commons' Industrial Goodwill (1919) to provide such a framework. The second part of this symposium, to be published in the March 2013 issue, will contain an article by John Budd in which he offers additional reflections on his ideas presented in The Thought of Work.

V. G. Devinatz $(\bowtie)$

Department of Management \& Quantitative Methods, Illinois State University, Normal, IL 61790-5580, USA

e-mail:vgdevin@ilstu.edu 
If any of the readers of this symposium are interested in commenting on these three essays in the journal's pages, please do not hesitate to contact me. Other symposiums on important employment relations topics are planned for future issues of the Employee Responsibilities and Rights Journal. If any of the journal's readers have suggestions for symposiums on specific topics, please do not hesitate to contact me. I hope that you enjoy this symposium and find it most illuminating. 